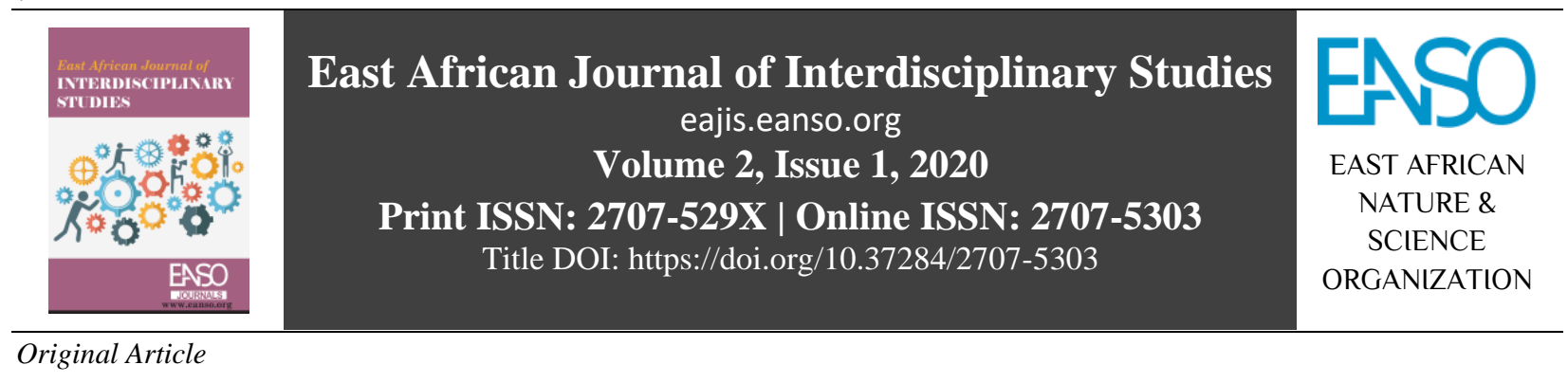

\title{
Provision of Food to Public Primary Schools and Its Effects on Enrolment of Pupils in Mara Ward, Narok West Sub-County, Narok County, Kenya
}

\author{
Rotich Paul Bii ${ }^{1^{*}} \&$ Dr. Stephen Tomno Cheboi ${ }^{1}$ \\ ${ }^{1}$ School of Education, Mount Kenya University. \\ *Author for Correspondence Email: rrotichbii@gmai.com
}

Article DOI: https://doi.org/10.37284/eajis.2.1.161

\begin{abstract}
Date Published: ABSTRACT
09 June 2020 The purpose of the study was to evaluate the relationship between the provision of food to public primary schools by FTC and the enrolment of pupils in Mara Ward of

Keywords: Narok West Sub-County, Narok County, Kenya. The study adopted descriptive survey research design. The target population was 131 public primary schools in

Provision of Narok West Sub-County, 1460 teachers and 3150 pupils. A sample of 97 schools, Food, 302 teachers and 344 pupils was drawn. Simple random sampling method in the Public Primary numbers of schools, teachers and pupils was used. Findings of the study showed that Schools, provision of food increased the enrolment rate of pupils in school. This is because Enrolment of meals programmes offered in schools enables the pupils from far and humble Pupils, backgrounds to have similar treatment to the pupils coming from better backgrounds Narok County. and close to the schools. These programmes increased the level of admission of new pupils thus increasing the rate of enrolment in most schools. However, offering food in schools does not automatically increase the rate of enrolment for it was realized that quality of food matters the most as well. The findings can help the government to sensitize on the quality of food being offered to be increased. Meals programmes should be implemented in all schools in Mara Ward and even to other parts of the country. In addition, the quality of the food offered should be increased to reduce diseases associated with malnutrition.
\end{abstract}

\section{APA CITATION}

Bii, R., \& Cheboi, S. (2020). Provision of Food to Public Primary Schools and Its Effects on Enrolment of Pupils in Mara Ward, Narok West Sub-County, Narok County, Kenya. East African Journal of Interdisciplinary Studies, 2(1), $20-27$. https://doi.org/10.37284/eajis.2.1.161

\section{CHICAgO CITATION}

Bii, Robert, and Stephen Cheboi. 2020. "Provision of Food to Public Primary Schools and Its Effects on Enrolment of Pupils in Mara Ward, Narok West Sub-County, Narok County, Kenya”. East African Journal of Interdisciplinary Studies 2 (1), $20-27$. https://doi.org/10.37284/eajis.2.1.161. 


\section{HARVARD CITATION}

Bii, R. and Cheboi, S. (2020) "Provision of Food to Public Primary Schools and Its Effects on Enrolment of Pupils in Mara Ward, Narok West Sub-County, Narok County, Kenya", East African Journal of Interdisciplinary Studies, 2(1), pp. 20-27. doi: 10.37284/eajis.2.1.161.

\section{IEEE CITATION}

R. Bii and S. Cheboi, "Provision of Food to Public Primary Schools and Its Effects on Enrolment of Pupils in Mara Ward, Narok West Sub-County, Narok County, Kenya”, EAJIS, vol. 2, no. 1, pp. 20-27, May 2020.

\section{MLA CITATION}

Bii, Robert, and Stephen Cheboi. "Provision of Food to Public Primary Schools and Its Effects on Enrolment of Pupils in Mara Ward, Narok West Sub-County, Narok County, Kenya". East African Journal of Interdisciplinary Studies, Vol. 2, no. 1, May 2020, pp. 20-27, doi:10.37284/eajis.2.1.161.

\section{INTRODUCTION}

Access to education is a fundamental and universal right to every child. Due to this, schools continue to be established across the globe. This is especially true for the marginalized areas, more so those characterized as hardship areas. The development in schools has increased the number of pupils in public primary schools further increasing the demand for additional schools and required amenities as they are critical tools for empowerment as well as fuel learning programs in schools.

In circumstances where there is nonattendance of major school workplaces. This is in light of the fact that school workplaces overhaul effective and beneficial learning ventures with the ultimate objective that failure to have them will diminish the school execution. As per the Nigeria Nation daily paper of October 2009, exhibit from open elementary schools in Nigeria was accounted for. This was because of deficient frameworks and other school offices and it, for the most part, showed that physical foundation in schools affects understudies' enthusiasm on getting the hang of relying upon their accessibility. It is presently obvious that there is an increment in individual and school execution and enlistment when the offices, for example, library gear and seats are given adequately.

Besides, current examinations done by Okunamiri (2010) in Nigeria shows that paying little heed to giving satisfactory offices to certain schools, they were not used effectively. In his investigation, the need for viable and proficient acknowledgement of objectives and targets of instruction framework was accentuated. Free the Children intervened in Narok county by providing physical facilities that are modern that have facilitated learning by learners.

Kwesiga (2012) noticed that school offices decided the nature of the school which thus impacts the accomplishments and enrolment. Ongoing investigations indicated that absence of security for young ladies, for example, the nonappearance or poor latrines add to intermittent truancy and at last lead to some young ladies dropping out of schools. The discoveries of Mwangi (2016) demonstrated that study halls and stationeries have an impact on understudies' enrolment. As per Mills and Gale (2004), the physical conditions under which an educator works in influences the youngsters' and their level of inspiration. A student isn't very much inspired on the off chance that the person is hunching down on an awkward stool. Most country schools are described by flimsy structures, absent or broken work areas and seats, and absence of good ventilation and sanitation offices. This had the net impact of debilitating school enrolment and participation (Mwangi, 2016). According to Munene (2019), the arrangement of helpful homerooms and research centres can make the subject extremely fascinating and energizing to the students and consequently urge more understudies to join the school. Understudies' accomplishment anytime is the collective capacity of sources of info, for example, research facilities, course books, school structures and libraries among others (Mwangi, 2016). Arrangement of stationeries and training helps is likewise basic to student's enrolment.

Maicibi (2003) asserts that when the right quantity and quality of human resources are brought together, they can manipulate other resources towards realizing institutional goals and objectives. 
Mwangi (2016) postulates that object well-handled practically impresses itself more firmly in the mind than the object merely seen from a distance. Pupilteacher ratio refers to the number of learners enrolled in a given level of education divided by the number of teachers in the system. Munene (2019) states that learning is strengthened when there are enough reference materials such as textbooks and teaching aids which can positively change teachers' and learners' attitudes.

Mwangi (2016) states that school sponsors provide educational support to primary school pupils' mainly in the form of textbooks, school uniform, school bags and hurricane lamps that help them to do private studies at home. This is aimed at ensuring that these children will be retained at school and will not be sent home because of lack of required textbooks or school uniform or schoolbag.

Mwangi (2016), in her study on the influence of educational resources on pupils' outcomes, defines educational resources or teaching-learning resources as all materials and equipment used to enhance effective learning. Her major concern is that there is a notable shortage of teaching materials and equipment in schools today. This is a problem which needs careful consideration for a solution to be reached. She laments at a situation whereby a teacher wants to teach reading in the absence of reading books, while at times, a teacher wants to write something on the chalkboard and there is no chalk. She strongly urges the school administrators to start exploring ways and means of how they can solve this problem because if it is left unsolved, the schools will go deeper and deeper into many problems which impact negatively on school achievements.

According to Mwangi (2016), reading textbooks is not the only problems that face schools on the side of teaching materials and equipment. There is an inadequate supply of many things in schools, just to mention a few like desks, tables, maps, pictures and posters. The journal article arrives at the conclusion that the success of any lesson depends on how well the teacher prepares his lesson, what type of equipment he uses and the use of teaching aids. This means that the availability of adequate education resources cannot be downplayed in the journey to excelling academically. To reduce these problems teaching resource centres would be helpful for teachers at which teachers can borrow items such as radio from the broadcasting lessons, tape recorders for teaching or all language lessons, cassette players, projectors and many other teaching equipment and materials.

In the US, student and teacher comfort are regarded as the most important aspect of the school Physical environment. If students are comfortable then learning becomes much easier where being comfortable involves adequate usable space, noise control, lighting, temperature and sanitation. The classroom is the most important area of the school because it is the area where the students and teachers spend most of their time and where most of the learning process takes place (Kaburu, 2014).

Kaburu (2014) noted that the availability of the school building and other plans contribute to good academic performance as they enhance teaching and learning activities. Other studies done in Botswana and New Guinea concur that pupils' enrolment is attributed to a number of school factors which include the provision of physical facilities, classroom size, effective school discipline policies, administrative support, and effective leadership (Muli, 2005). Orodho (2003) in his study on access and participation in secondary education in Kenya found that physical facilities and instructional materials are quite crucial to students learning. FPE has stretched facilities to the limit, classrooms are congested, desks are inadequate and so are textbooks. According to Kaburu (2014) and Mangi (2016), the number of classes, availability of libraries, the ratio of toilets to students, defines an ideal environment for learning as it makes girls and boys feel safe and able to achieve their full intellectual, physical and emotional potentials. Kaburu (2014) and Mangi (2016), defines school as an institution with specialized personnel apparatus, formal and stereotyped means of instructions, a curriculum and rational defined manifesto and objectives. Physical facilities determine the quality of the school which in turn influences the achievements and enrolment rates of its pupils. Studies show that lack of privacy for girls such as the absence or poor toilet facilities contribute to periodic truancy and ultimately lead to some girls dropping out of schools, Kwesiga (2012). 
Pedagogical principles and school resources are substantive hypothesis and facilitation about teaching and learning of the pupils, (Kaburu, 2014). According to Mangi (2016), Uganda's UPE policy was a successful program in bringing a massive influence of new, predominantly poorer students into government schools. He further asserts that when the right quantity and quality of human resources are brought together, it can manipulate other resources towards realizing institutional goals and objectives. He states that learning is strengthened when there are enough reference materials such as textbooks. Teaching aids can positively change teachers' and learners' attitudes. School sponsors provide educational support to primary school pupils. This is in the form of textbooks, school uniform, school bags and hurricane lamps that help them to do private studies at home. This is aimed at ensuring that these children will be retained at school and will not be sent home because of lack of required textbooks or school uniforms or schoolbags. The findings of Kaburu (2014) and Mangi (2016) have shown that classrooms, teaching aids and stationeries influence pupils' enrolment. Further, they argue that learning is strengthened when there are enough reference materials such as textbooks and classrooms.

\section{Statement of the Problem}

When it comes to access to basic education in Kenya, there exist inequalities such that Arid and Semi-arid lands (ASALs) are the most hit despite the effort by the government to introduce free primary education. Since there are frequent prolonged dry seasons in Narok County, it's one of the ASAL areas with inadequate food security. Some of the factors that have caused food insecurity are inadequate rainfall, aridity and higher evaporation rate than the rainfall hence high water loss. Insecurity within the County is due to conflicts over the few resources, for example, the water and pasture. According to Orodho 2003, the children who live in arid and semi-arid lands have lower school enrolment and completion rates. Access to primary school is limited due to malnutrition.

In Narok West Sub-County, Mara Ward hundreds of pupils miss school due to hunger. The situation is worrying because every day, the number of pupils attending school is diminishing. According to the statistics by Narok County Director of Education, most of the schools in Mara Ward have their population dropping. In addition, learning in some schools in Narok has been affected by hunger. Pupils have opted to stay out of school and look for food. The proponents of school feeding programs indicate that the provision of food in schools would enhance increment in enrolment and attendance, improvement in academic achievement, decrease in school drop-outs and attraction of more vulnerable children to school (Adelman \& Gilligan, 2018).

This study adopted quantitative research approaches. The design helped the researcher obtain information from a broad spectrum of the population (Mugenda \& Mugenda, 2003). Descriptive survey design is a data collection method that entails directing questionnaires to sampled individuals. In agreement with that, Oso and Onen (2008), argued that descriptive questionnaires are used in investigating populations by assembling samples and analysing various variables to discover and make inferences about a phenomenon. This makes them relevant in this research. This study aimed at investigating the opinions of the respondents in relation to the influence of SFP on primary schools' enrolment. The researcher used public primary schools in Narok West Sub-County which was in agreement with Kombo and Tomp (2006), arguing that data collection, analysis and interpretation should be developed from available information. This was done to determine the influence of school feeding programs (SFP) on public primary schools' enrolment and academic performance in Mara Ward, Narok County.

\section{Sample Size and Sampling Procedure}

Since it was impracticable to access the entire target population of one hundred and forty-six (146) primary schools in the study area, the investigator had to draw a representative sample. Unit of analysis of the study was 146 public primary schools, 1460 teachers and 3500 class 8 pupils in Mara Ward of Narok County. Krejcie and Morgan (1970) table was used to determine the sample size hence 97 schools, 302 teachers and 344 pupils were used as sample size. Simple random sampling technique was used to sample the schools, teachers and pupils. 


\section{Data Collection and Analysis}

The study used questionnaires for data collection. The questionnaires for teachers were numbered 1302. Teachers filled the questionnaires before being collected on the same day. The questionnaires captured information on registration, turnout, the role of stakeholders and factors that hindered the provision of school feeding programs (SFP) in Narok West sub-County. Questionnaires were administered to pupils where they were required to fill them with the guidance from the researcher. The researcher ensured that the pupils understood the questions before administering them. The questionnaire captured information on registration, turnout, role of stakeholders and factors that hindered the provision of SFP in Narok West subCounty. A five-point Likert scale was used, categorized as $\mathrm{SA}=$ Strongly Agree, $\mathrm{A}=$ Agree, $\mathrm{N}=$ Neutral, $\mathrm{D}=$ Disagree, $\mathrm{SD}=$ Strongly Disagree.

The questionnaires were checked to determine their correctness, extensiveness and determining items that were incorrectly responded to, grammatical errors and blank spaces left by the respondent.
Computable data were then keyed into the computer for analysis using Statistical Package for Social Sciences (SPSS) version 23.0. Descriptive statistics such as percentages, frequencies, mean and standard deviations were used for data analysis and the results were presented in tables.

\section{Ethical Considerations}

The researcher obtained clearance and approval from Mount Kenya Ethical Review Committee to apply for issuance of authorization letter and permit from NACOSTI. The investigator assured the respondents on the confidentiality of information. The researcher isolated information and kept away from any third-party access and interference. The respondents were assured that the data they offered would be used only for this specific study.

\section{FINDINGS AND DISCUSSIONS}

The study sought to determine the influence of the provision of food on enrolment rate of pupils in school.

\section{Table 1: Teachers' Perception of the Influence of the Provision of Food on Enrolment of Pupils}

\begin{tabular}{|c|c|c|c|c|c|}
\hline Description & SD/D & $\mathbf{N}$ & SA/A & Mean & Std. Dev. \\
\hline There is a meals program in our institution & $\begin{array}{l}64 \\
(21.2 \%)\end{array}$ & $\begin{array}{l}12 \\
(4.0 \%)\end{array}$ & $\begin{array}{l}222 \\
(73.5 \%)\end{array}$ & 4.07 & 1.583 \\
\hline There is high level of admission in our school & $\begin{array}{l}13 \\
(4.3 \%)\end{array}$ & $\begin{array}{l}71 \\
(23.5 \%)\end{array}$ & $\begin{array}{l}218 \\
(72.2 \%)\end{array}$ & 3.77 & 0.738 \\
\hline $\begin{array}{l}\text { There is school feeding program in your sub- } \\
\text { county }\end{array}$ & $\begin{array}{l}59 \\
(19.5 \%)\end{array}$ & $\begin{array}{l}24 \\
(7.9 \%)\end{array}$ & $\begin{array}{l}213 \\
(70.5 \%)\end{array}$ & 4.08 & 1.465 \\
\hline $\begin{array}{l}\text { There has been an increase in enrolment } \\
\text { since the introduction of school feeding } \\
\text { programme. }\end{array}$ & $\begin{array}{l}53 \\
(17.5 \%)\end{array}$ & $\begin{array}{l}19 \\
(6.3 \%)\end{array}$ & $\begin{array}{l}225 \\
(74.6 \%)\end{array}$ & 4.08 & 1.438 \\
\hline Food provided in school are of high quality & $\begin{array}{l}68 \\
(22.5 \%)\end{array}$ & $\begin{array}{l}25 \\
(8.3 \%)\end{array}$ & $\begin{array}{l}209 \\
(69.2 \%)\end{array}$ & $3 . .92$ & 1.584 \\
\hline
\end{tabular}

Teachers were asked to indicate their level of agreement with the influence of the provision of food on the enrolment of pupils in school. Table 1 shows that, $64(21.2 \%)$ respondents disagreed when asked whether there is a meals program in their institution, $12(4.0 \%)$ respondents were neutral, majority of $222(73.5 \%)$ respondents agreed while $4(1.3 \%)$ respondents did not indicate their responses. The mean of this was 4.07 with a standard deviation of 1.583 , this is so because the majority of the respondents agreed strongly suggesting that provision of meals in school improves the enrolment rate of pupils in school. This tally with the findings of the study done by Obonyo et al. (2009) which found that meals programs are very crucial and they increase the rate of enrolment in schools.

On whether there is high level of admission in 13 $(4.3 \%)$ of the teacher respondents disagreed, 71 $(23.5 \%)$ were neutral while the majority of 218 $(72.2 \%)$ agreed. The mean of this was 3.77 with a 
standard deviation of 0.738 , this is so because majority of the respondents were agreeing. However, having some disagreeing, it is an indication that the admission level should be equally improved in all schools. This corroborates with the findings of the study done by Lambers (2009) where he asserted that school feeding program increases the rate of admission in schools. When asked whether there were school feeding programmes in their schools, 59 (19.5\%) respondents disagreed, $24(7.9 \%)$ respondents were neutral, majority of $213(70.5 \%)$ respondents agreed while $6(2.0 \%)$ respondents did not indicate their responses. The mean of this was 4.08 with a standard deviation of 1.465 , this is so because majority of the respondents were agreeing strongly. This is in agreement with the study done by Kristjansson et al. (2007) where most schools were sensitized to have meal programmes.

Teachers were asked whether there has been increase in enrolment since the introduction of school feeding programme; 53 (17.5\%) respondents disagreed, $19(6.3 \%)$ were neutral, majority of 225 (74.6\%) respondents agreed while $5(1.7 \%)$ respondents did not indicate their responses. The mean of this was 4.08 with a standard deviation of 1.438 , this is so because majority of the respondents were agreeing strongly. However, a portion of respondents disagreed strongly sending a message that in some schools, even after the introduction of school feeding programs, still there are factors that hinder enrolment rate. This is in agreement with the study done by Del Rosso and Arlianti (2009) where he asserted that the provision of meals in school increases the rate of enrolment in school.

On whether the meals provided in school are of high quality, 68 (22.5\%) respondents disagreed, 25 $(8.3 \%)$ respondents were neutral and majority of $209(69.2 \%)$ respondents agreed. The mean of this was 3.92 with a standard deviation of 1.584 , this is so because majority of the respondents were agreeing strongly, however, a good percentage of respondents disagreed strongly giving an indication that some schools offer low-quality meals to pupils. This will help the government to counter check on the quality of meals pupils are given in various schools not only in Mara ward but also in the rest of the locations. This tallies with the findings of the study done by Berg (2011) whereby the provision of quality meals was concluded to increase the enrolment rate in schools.

Table 2: Pupils' Perception of the Influence of the Provision of Food on Enrolment Rate

\begin{tabular}{|c|c|c|c|c|c|}
\hline Description & SD/D & $\mathbf{N}$ & SA/A & Mean & $\begin{array}{l}\text { Std. } \\
\text { Dev. }\end{array}$ \\
\hline Meals are offered in our school & $\begin{array}{l}68 \\
(19.8 \%)\end{array}$ & $\begin{array}{l}14 \\
(4.1 \%)\end{array}$ & $\begin{array}{l}258 \\
(75 \%)\end{array}$ & 4.13 & 1.540 \\
\hline There is high level of admission in our school & $\begin{array}{l}13 \\
(3.8 \%)\end{array}$ & $\begin{array}{l}75 \\
(21.8 \%)\end{array}$ & $\begin{array}{l}256 \\
(74.5 \%)\end{array}$ & 3.8 & 0.712 \\
\hline In our Sub-County, there is feeding program & $\begin{array}{l}46 \\
(13.3 \%)\end{array}$ & $\begin{array}{l}42 \\
(12.2 \%)\end{array}$ & $\begin{array}{l}254 \\
(73.9 \%)\end{array}$ & 4.25 & 1.257 \\
\hline Enrolment rate increased since the introduction of SFP & $\begin{array}{l}17 \\
(4.9 \%)\end{array}$ & $\begin{array}{l}15 \\
(4.4 \%)\end{array}$ & $\begin{array}{l}312 \\
(80.7 \%)\end{array}$ & 4.58 & 0.899 \\
\hline Our school provides quality food & $\begin{array}{l}65 \\
(18.9 \%)\end{array}$ & $\begin{array}{l}26 \\
(7.6 \%)\end{array}$ & $\begin{array}{l}247 \\
(71.8 \%)\end{array}$ & 4.12 & 1.441 \\
\hline
\end{tabular}

Pupils were asked to indicate their level of agreement with the influence of provision of food on enrolment rate in their school. Table 2 shows that $68(19.8 \%)$ respondents disagreed when asked whether there is a meals program in their school, 14 $(4.1 \%)$ respondents were neutral and majority of $258(75 \%)$ respondents agreed. The mean of this was 4.13 with a standard deviation of 1.540 . This is so because majority of the respondents agreed that the provision of meals in school improves the enrolment rate of pupils in school. This tally with the findings of the study done by Kaufmann and Karpati (2007) where they asserted that meals 
programme is very crucial and it increases the rate of enrolment rate in schools.

On whether there is high level of admission in school, 13 (3.8\%) pupils respondents disagreed, 75 (21.8\%) respondents were neutral while majority of $256(74.5 \%)$ respondents agreed. The mean of this was 3.8 with a standard deviation of 0.712 , this is so because majority of the respondents were agreeing, however having some disagreeing gives an indication that admission level should be equally improved in all schools. This corroborates with the findings of the study done by Salee (2013) asserting that the school feeding program increases the rate of admission in schools.

Asked whether there is school feeding programme in their schools, $46(13.3 \%)$ respondents disagreed, $42(12.2 \%)$ respondents were neutral and majority of $254(73.9 \%)$ respondents agreed. The mean of this was 4.25 with a standard deviation of 1.257 , this is so because majority of the respondents were agreeing. This is in agreement with the study done by Greenhalgh, Kristjansson and Robinson (2007) where they called for the government to fund schools to have meal programmes.

Pupils were asked whether there has been increase in enrolment since the introduction of school feeding programme; $17(4.9 \%)$ respondents disagreed, $15(4.4 \%)$ respondents were neutral while majority of $312(80.7 \%)$ respondents agreed. The mean of this was 4.58 with a standard deviation of 0.897 , this is so because majority of the respondents were agreeing, however, a portion of respondents disagreed sending a message that in some schools, even after the introduction of school feeding programs, still there are factors that hinder enrolment rate. This is in agreement with the study done by Del Rosso and Arlianti (2009) where he asserted that the provision of meals in school increases the rate of enrolment in school.

On whether food provided in school are of high quality, $65(18.9 \%)$ respondents disagreed, 26 (7.6\%) respondents were neutral and majority of $247(71.8 \%)$ respondents agreed. The mean of this was 4.12 with a standard deviation of 1.441 , this is so because majority of the respondents were agreeing, however, a good percentage of respondents disagreed giving an indication that some schools offer low-quality meals to pupils.
This will help the government to counter check on the quality of meals pupils are given in various schools not only in Mara ward but also in the rest of the locations. This, however, tallies with the findings of the study done by Berg (2011) whereby the provision of quality meals was concluded to increase the enrolment rate in schools.

\section{CONCLUSIONS AND RECOMMENDATION}

It was concluded that the provision of food increased the enrolment rate of pupils in school. This is because meals programme offered in schools enables the pupils from far and humble backgrounds to have similar treatment to the pupils coming from better backgrounds and close to school. This programme increases the level of admission of new pupils thus increasing the rate of enrolment in most schools. Offering food in schools does not automatically increase the rate of enrolment.

It was realized that the quality of food matters the most as well. This indication will, therefore, help the government to sensitize the quality of food being offered to be increased. Meals programme should be implemented in all schools in Mara Ward and even to other parts of the country. On this, the quality of the food offered should be increased to reduce diseases associated with low-quality foods. Meals programme should be implemented in all schools in Mara Ward and even to other parts of the country. On this, the quality of the food offered should be increased to reduce diseases associated with low-quality foods.

\section{REFERENCES}

Berg, J. (2011). All you can eat: How hungry is America?. Seven Stories Press.

Del Rosso, J. M., \& Arlianti, R. (2009). Investing in school health and nutrition in Indonesia. World Bank.

Greenhalgh, T., Kristjansson, E., \& Robinson, V. (2007). Realist review to understand the efficacy of school feeding programmes. Bmj, 335(7625), 858-861. 
Kaburu, V. A. (2014). Influence of School Environment on Pupils' Enrolment in Public Primary Schools in Kenya; A Case of Hamisi Sub-County (Doctoral dissertation). University of Nairobi.

Kaufman, L., \& Karpati, A. (2007). Understanding the sociocultural roots of childhood obesity: food practices among Latino families of Bushwick, Brooklyn. Social science \& medicine, 64(11), 2177-2188.

Kombo, D. K., \& Tromp, D. L. (2006). Proposal and thesis writing: An introduction. Nairobi: Paulines Publications Africa.

Krejcie, R. V., \& Morgan, D. W. (1970). Determining sample size for research activities. Educational and psychological measurement, 30(3), 607-610.

Kristjansson, B., Petticrew, M., MacDonald, B., Krasevec, J., Janzen, L., Greenhalgh, T., ... \& Mayhew, A. (2007). School feeding for improving the physical and psychosocial health of disadvantaged students. Cochrane database of systematic reviews, (1).

Kwesiga, J. C. (2002). Women Access to Higher Education in Africa. Kampala: Uganda Experience Foundation Publishers LTO.

Lambers, W. (Ed.). (2009). Ending World Hunger: School Lunches for Kids around the World: Interviews with Officials from the United Nations World Food Programme about School Feeding Initiatives that Fight Child Hunger. William Lambers.

Maicibi, N. A. (2003). Human Resource Management Success. Kampala, Uganda: Net Media Publication Ltd.

Mills, C., \& Gale, T. (2004). Parent participation in disadvantaged schools: Moving beyond attributions of blame. Australian Journal of Education, 48(3), 268-281.

Mugenda, O. M. \& Mugenda, A. G. (2003). Research methods: Quantitative and qualitative Approaches. Nairobi: African Centre for Technology Studies.
Muli. M. M. (2015). Effects of Head Teachers' Management Styles on Performance in Physics at KCSE Examination in Mutomo Division, Kitui District. Unpublished MED Project. University Of Nairobi.

Munene, B. M. (2019). School Based Factors Influencing Teacher Turnover in Public Primary Schools in Mathioya Sub-county Murang'a County, Kenya (Doctoral dissertation). University of Nairobi.

Mwangi, J. W. (2016). School Based Factors Influencing Teacher Performance in Implementation of Curriculum in Public Primary Schools in Njoro Sub-county, Nakuru County, Kenya (Doctoral dissertation. University of Nairobi.

Obonyo, J. A., Oronje, D. O., Shitote, Z., Onyango, V. O., Barigira, B. G., Nderi, A. N., ... \& Ogutu, C. A. (2009). Effects of School Feeding Program on Pupils Participation in Public Day Primary Schools in Yala Division, Kenya. University of Nairobi.

Okunamiri, P. O. (2010). Educational Planning and Policy Analysis. Owerri: Novelty Industry Enterprises Limited.

Orodho, A. J. (2003). Essentials of educational and social science research methods. Nairobi: Masola Publishers.

Oso, W. Y. \& Onen D. (2008). A General Guide to Writing Research Proposal and Report. Kampala: Makerere University Printers.

Salee, M. D. (2013). Influence of school feeding program on pupils' participation in public primary schools in Masinga division in Machakos County [Unpublished Master's project]. Nairobi, Kenya: University of Nairobi. 